\title{
Nucleoprotein TPR
}

National Cancer Institute

\section{Source}

National Cancer Institute. Nucleoprotein TPR. NCI Thesaurus. Code C97857.

Nucleoprotein TPR (2363 aa, $267 \mathrm{kDa}$ ) is encoded by the human TPR gene. This protein plays a role in both mitotic spindle assembly and nuclear membrane transport. 